\title{
Evaluating the Effect of Foeniculum Vulgare Extract On Enzymes Related With Blood Pressure and Diabetes (In Vitro Study)
}

\author{
Ahmed Abu-Zaiton ${ }^{1}$, Muhammad Alu'datt ${ }^{2}$, and Wafa Mohamed Ali ${ }^{1}$
}

\begin{abstract}
This study was conducted to evaluate the effect of various extractions conditions for phenolic compounds from $F$. vulgare on biological properties including angiotensin converting enzyme (ACE), $\alpha$-amylase and $\alpha$-glucosidase inhibitory activities. Contents of extracted phenolic compounds from $F$. vulgare were evaluated using different extraction conditions include different times, temperatures and solvents. The extracted phenolic compounds were subjected to evaluate the optimum extraction conditions of inhibitory activities (\%) of ACE, $\alpha$-amylase and $\alpha$-glucosidase enzymes. Results showed that the maximum content of extracted phenolic compounds was found in mixture of methanol and water at $45 \mathrm{C}^{\circ}$ for $8 \mathrm{hrs}$. On the other hand, the best extraction conditions with maximum value of inhibitory activity of $\mathrm{ACE}$ were found in methanol extract at $37 \mathrm{C}^{\circ}$ for $8 \mathrm{hrs}(\mathbf{5 0 . 8 \%})$. Through optimization process, it was observed that $\alpha$-glucosidase and $\alpha$-amylase inhibition levels were methanol extract at $25 \mathrm{C}^{0}$ for 8 hrs with values of $82.26 \%$ and $82.43 \%$ respectively. It may be concluded that the extracted phenolic compounds from $F$. vulgare have higher effect as antidiabetic and moderate effect as antihypertensive.
\end{abstract}

Keywords-Angiotensin Converting Enzyme, a-amylase, a-glucosidase, Foeniculum vulgare.

\section{INTRODUCTION}

Hypertension and diabetes are interrelated metabolic disorders (Bakris et al., 2000). One of the major determinants to the development of T2DM is postprandial hyperglycemia. According to Ceriello et al. (2005) postprandial hyperglycemia refers to the abnormal blood glucose level after a meal, usually caused by insulin resistance or combined with insulin deficiency. It is therefore essential to understand that the majority of blood glucose comes from the hydrolysis of dietary carbohydrates by pancreatic $\alpha$-amylase and intestinal $\alpha$-glucosidase (Grabitske and Slavin, 2009). A potential hyperglycemia treatment focuses on the inhibition of these enzymes, causing retardation in carbohydrate digestion and subsequently reducing glucose absorption rate into the bloodstream (Nathan et al., 2006).

Digestive enzymes related T2DM would delay the degradation of starch and oligosaccharides, which would in turn cause a decrease in the absorption of glucose and consequently inhibit the increase in postprandial blood glucose. In particular, $\alpha$-amylase and $\alpha$-glucosidase participate in glucose digestion are considered as key enzymes that can control postprandial

Ahmed Abu-Zaiton, Muhammad Alu'datt, and Wafa Mohamed Ali are with Al-albayt University, Jordan University of Science and Technology. hyperglycemia (Ali et al., 2006; Lee et al., 2007). Alpha-amylase is present in both salivary and pancreatic secretion (Ramasubbu et al., 2004). It is responsible for cleaving of large malto-oligosaccharides to maltose, which is then a substrate for intestinal $\alpha$-glucosidase. Several studies evaluated the ability of plant extracts and compounds to inhibit both $\alpha$-amylase and $\alpha$-glucosidase (Conforti et al., 2005; Kotowaru et al., 2006).

Hypertension is responsible for 50\%-80\% of deaths in people with diabetes (Shlipak et al., 2001). Hypertension is high pressure in the arteries that carry blood from pumping heart to all the tissues and organs of the body. It is mainly two types: Primary or essential hypertension has no specific cause which may contribute to increase in blood pressure (kumar et al., 2011). Secondary hypertension caused by underlying diseases like renal damage, pheochromocytoma, muscular disorders which may eventually result in cerebrovascular accidents and cardiovascular disease (Segura and Ruilope, 2006). Excessive activation of the renin angiotensin system (RAS) has been considered to be a main cause of hypertension which regulated by angiotensin converting enzyme (ACE) (Appel, 2010). ACE inactivates the vasodepressor compound bradykinin and activates the potent vasoconstrictor and growth-promoting substance angiotensin II by the removal of the carboxy-terminal dipeptide of angiotensin I (Paul et al., 2006). The importance of ACE inhibitors in the chronic treatment of various cardiovascular diseases established and several ACE inhibitors are currently used in the treatment of hypertension (Carson, 2000).

Foeniculum vulgare commonly known as fennel is one of the widespread annual or perennial plants with aromatic odor. It was native to Southern Europe and Mediterranean region (Oktay et al., 2003). Vulgare and Piperitum two important subspecies of fennel. F. Piperitum, with bitter seeds, and is characterized by the presence of rotundifolone, while $F$. vulgare, with sweet seeds varied with estragole, trans-anethole, limonene and fencing, by which different chemo types can be divided (Muckensturm et al., 1997). Little information has been reported about the anti-diabetic and anti-hypertensive properties of aerial parts of $\mathrm{F}$. vulgare.

The present study however attempt to investigate the optimum extractions conditions for phenolic compounds from F. vulgare using different times, temperatures, and solvents andthen to study the biological properties of phenolic extracts (inhibitory activities of angiotensin converting, $\alpha$-amylase and $\alpha$-glucosidase enzymes). 


\section{MATERIALS AND METHODS}

\section{A. Plants Materials}

$F$. vulgare was collected from Irbid city that lies $65 \mathrm{~km}$ north the capital Amman, the aerial parts $F$. vulgare was air dried and shade, the leaves of $F$. vulgare were ground in an electric grinder to give a fine powder.

\section{B. Optimization of Extraction Conditions}

The bioactive compounds were extracted based on procedure described by Preva-uzunalic et al. (2007) with modifications. The optimization contents and biological properties of phenolic compounds using the following extraction parameters including temperature, time and solvent were studied. One gram of plant sample was subjected to the following extraction conditions including time; $0.5,1,2,4,6$ and $8 \mathrm{hrs}$. using $25 \mathrm{ml}$ of different extraction solvents; methanol (ME), acetone (AC), distilled water (DW), and combination of solvents at different extraction temperatures; 25,37 and $45^{\circ} \mathrm{C}$. The extract was filtered into 25 $\mathrm{ml}$ volumetric flask using whatman No.2 filter paper. The extract volume was completed to final mark of volumetric flask. The free and bound phenolic compounds were extracted from F. vulgare as described by the method of Alu'datt et al. (2012).

\section{Determination of inhibitory activity of $A C E$}

The inhibitory activity of ACE was determined in vitro using the method of Cushman and Cheung (1971) with some modifications (Alu'datt et al, 2012).

\section{Determination of inhibitory activity of $\alpha$-glucosidase}

The inhibitory activity of $\alpha$-glucosidase was evaluated using the method previously described by Bernfeld (1955) with modifications (Alu'datt et al., 2012).

\section{E. Determination of inhibitory activity of $\alpha$-amylase}

The inhibitory activity of $\alpha$-amylase was determined according to the method described by McCue et al. (2005). With modifications (Alu'datt et al., 2012).

\section{Statistical ANALYSES}

All experiments were performed at least in duplicates. Analysis at every time point from each experiment was carried in duplicates. Means and standard errors were calculated from duplicates within the experiments and analyses were done using the procedure of SAS Version 8.2 software package (SAS 2002 Institute Inc., Gary, NC, USA). The results were statistically analyzed by least significant deference (LSD) Statistical significance was accepted at a level of $\mathrm{P}<0.05$.

\section{RESUlT AND DISCUSSION}

\section{A. Effect of extraction solvent conditions on contents of phenolic compounds}

Table 1. Shows the effect of extraction solvent conditions on the total content of phenolic compounds using methanol, acetone, water and mixture of solvents at $18^{\circ} \mathrm{C}$ for $1 \mathrm{hr}$. The content of phenolic compounds was varied significantly using different solvents and mixtures of extraction conditions. Result indicates that the maximum content of phenolic compound was obtained in mixture of methanol and water extract (1:1) with values of $36.89 \mathrm{mg} / \mathrm{g}$. While the lowest contents of phenolic compound were obtained in methanol and acetone extract with value of $12.27 \mathrm{mg} / \mathrm{g}$. The variations in contents of phenolic compounds in extracts may be related to chemical composition and structure of phenolic compounds which had a wide range of polarity (Gonz' alez et al., 2010).

\section{B. Effect of Extraction Solvent of extracted phenolic compounds on Inhibition of ACE and diabetic enzymes}

Table 1 shows Effect of Extraction Solvent of extracted phenolic compounds on Inhibition of ACE and diabetic enzymes .The maximum capacity of ACE inhibition for phenolic extracts was observed in a combination of methanol, acetone and water mixture $(1: 1: 1)$ extract with a value of $26.53 \%$. The minimum capacity of ACE inhibition of phenolic extract was obtained in a combination of acetone and water mixture (1:1) with value of $9.22 \%$ (Table 1 ). The inhibitory activity of ACE of peptides can be extracted by organic solvents including enzyme hydrolysis and microbial fermentation (Choi et al., 2001). The ACE inhibitory activity of extracted phenolic compounds from pulverized mushroom and sonicated broccoli were higher in water extract as compared to organic solvents extractions (Lee et al., 2004). Castro et al. (2000) reported that the ACE inhibitory activity of water and ethanol extractions from $F$. vulgare were 50 and $61 \%$, respectively.

TABLE I: EFFECT OF EXTRACTION SOLVENT ON TOTAL PHENOLIC COMPOUNDS CONTENT (MG/G) ***, ACE INHIBITOR ACTIVITY $(\%)$, A-GLUCOSIDASE INHIBITOR ACTIVITY $(\%)$ AND A-AMYLASE INHIBITOR ACTIVITY (\%) AT $18^{\circ} \mathrm{C} / 1$ HR FOR $F$. VULGARE PLANT

\begin{tabular}{|c|c|c|c|c|}
\hline Extraction Solvent & $\begin{array}{l}\text { Total } \\
\text { phenolic }\end{array}$ & $\begin{array}{l}\text { Inhibitor } \\
\text { activity } \\
\text { of ACE }\end{array}$ & $\begin{array}{l}\text { Inhibitor } \\
\text { activity of } \\
\alpha \text {-amylase }\end{array}$ & $\begin{array}{l}\text { Inhibitor } \\
\text { activity of } \\
\alpha \text {-glucosidase }\end{array}$ \\
\hline $\begin{array}{l}\text { Methanol:Acetone: } \\
\text { D. } W^{* * *}(1: 1)\end{array}$ & $33.35^{\mathrm{ab}^{*}}$ & $26.53^{\mathrm{a}}$ & $32.15^{\mathrm{b}}$ & $19.97^{\mathrm{b}}$ \\
\hline $\begin{array}{l}\text { Distilled water: } \\
\text { Acetone }(1: 1)\end{array}$ & $31.2^{\mathrm{b}}$ & $9.22^{c}$ & $25.91^{\mathrm{c}}$ & $15.94^{\mathrm{c}}$ \\
\hline $\begin{array}{l}\text { Methanol: Distilled } \\
\text { water }(1: 1)\end{array}$ & $36.89^{\mathrm{a}}$ & $17.96^{\mathrm{b}}$ & $13.62^{d}$ & $16.69^{c}$ \\
\hline $\begin{array}{l}\text { Methanol: } \\
\text { Acetone(1:1) }\end{array}$ & $12.27^{\mathrm{c}}$ & $24.59^{\mathrm{a}}$ & $48.35^{\mathrm{a}}$ & $34.72^{\mathrm{a}}$ \\
\hline $\mathrm{SE}^{* * * * * *}$ & 1.37 & 0.76 & 1.49 & 0.65 \\
\hline
\end{tabular}

*values with different letters in the same column are significantly different at $p<0.05$

$* * \mathrm{D} . \mathrm{W}=$ distilled water

*** The values are means for two replicates and expressed as $\mathrm{mg}$ of Gallic acid equivalent (GAE)/g(of dry matter from the sample).

$* * * * \mathrm{SE}=$ Standard

The highest value of $\alpha$-glycosidase inhibition was obtained in a mixture of methanol and acetone extract with a value of $34.72 \%$. However, the lowest value of inhibition level of $\alpha$-glycosidase was found in mixture of acetone and water extract (15.94\%). McCue. (2005) reported that the inhibitory activities of $\alpha$-glucosidase in water extracts of soybean were in the range of 1 to1. $2 \%$. The methanol extract of eucalyptus gave the inhibitory activities of $\alpha$-glucosidase with range values of 20 to 93\% (Basak et al., 2010). Table 1.

In this study, the maximum value of $\alpha$-amylase inhibition level was obtained with a mixture of methanol and acetone extract 
with value $48.35 \%$. While the lowest value of $\alpha$-amylase inhibitory level was obtained with a mixture of methanol and water extracted $(13.62 \%)$.

In study conducted by Mohamed et al. (2010) reported that bioactive compounds of $F$. vulgare extracted by different solvent, methanol, ethanol and acetone. They observed the methanol was best solvent to give bioactive components could be flavonols or phenolic acids. According to Maria et al. (2011) these compounds link between polyphenols and anti-diabetes activity of herbal extracts. In addition, in-vitro $\alpha$ - amylase inhibitory activity of the leaf and flower extracts of six ornamental plants have been evaluated. The comparative study proves that most of the organic solvents of these plants possess high inhibitory activity in their organic extracts which shows that the inhibitory compound might be an organic substance and non-polar (Bhandari and Jong, 2008).

\section{Effect of Extraction Time at $25 C^{\circ}$ on the Content of Phenolic, ACE and Diabetic enzymes in F. vulgare}

Table 2. Demonstrate the effect of time at $25 \mathrm{C}^{\circ}$ of extract on total phenolic content using methanol extraction in $F$. vulgare plant. The content of phenolic extracted from $F$. vulgare plant increased gradually from $0.5 \mathrm{hr}$. to $8 \mathrm{hr}$.

TABle II: CONTENT of Phenolic Compounds (MG/G), ACE INHIBITOR LEVEL (\%), A-GLUCOSIDASE INHIBITORY LEVEL (\%) AND A-AMYLASE INHIBITORY LEVEL (\%) FOR METHANOL EXTRACT USING DIFFERENT TIME AT $25 \mathrm{C}^{\mathrm{O}}$

\begin{tabular}{|l|l|l|l|l|l|l|l|}
\hline \multirow{2}{*}{$\begin{array}{l}\text { Biological } \\
\text { properties }\end{array}$} & \multicolumn{6}{|l|}{$25 \mathrm{C}^{\mathrm{o}}$} \\
\cline { 2 - 8 } & $0.5 \mathrm{~h}$ & $1 \mathrm{~h}$ & $2 \mathrm{~h}$ & $4 \mathrm{~h}$ & $6 \mathrm{~h}$ & $8 \mathrm{~h}$ & $\mathrm{SE}^{* * *}$ \\
\hline Total phenol $^{* *}$ & $12.09^{\mathrm{b}^{*}}$ & $14.81^{\mathrm{a}}$ & $14.62^{\mathrm{a}}$ & $14.88^{\mathrm{a}}$ & $14.68^{\mathrm{a}}$ & $15.2^{\mathrm{a}}$ & 0.24 \\
\hline $\begin{array}{l}\text { ACE inhibitory } \\
\text { level }\end{array}$ & $23.09^{\mathrm{c}}$ & $45.32^{\mathrm{a}}$ & $13.45^{\mathrm{d}}$ & $15.78^{\mathrm{d}}$ & $16.37^{\mathrm{d}}$ & $33.33^{\mathrm{b}}$ & 1.72 \\
\hline $\begin{array}{l}\alpha \text {-amylase } \\
\text { inhibitory level }\end{array}$ & $55.95^{\mathrm{bc}}$ & $47.04^{\mathrm{c}}$ & $57.44^{\mathrm{b}}$ & $63.37^{\mathrm{b}}$ & $64.12^{\mathrm{b}}$ & $82.43^{\mathrm{a}}$ & 2.97 \\
\hline $\begin{array}{l}\alpha \text {-glucosidase } \\
\text { inhibitory level }\end{array}$ & $17.43^{\mathrm{c}}$ & $37.55^{\mathrm{d}}$ & $42.47^{\mathrm{c}}$ & $43.51^{\mathrm{c}}$ & $47.54^{\mathrm{b}}$ & $82.26^{\mathrm{a}}$ & 1.15 \\
\hline
\end{tabular}

*values with different letters in the same row are significantly different at $\mathrm{p}<0.05$

** The values are means for two replicates and expressed as $\mathrm{mg}$ of Gallic acid equivalent (GAE)/g (of dry matter from the sample).

$* * * \mathrm{SE}=\mathrm{Standard}$ error

The highest yield of phenolic compounds at $25^{\circ} \mathrm{C}$ was at $8 \mathrm{hrs}$. with a value of $15.20 \mathrm{mg} / \mathrm{g}$. While the lowest yield was at $0.5 \mathrm{hr}$. with a value of 12.09 . Onofre et al. (2007) reported that the phenolic yield in rice bran was increased with increasing time. Results in Table. 2. Revealed ability of $F$. vulgare extract to ACE inhibition was observed at $1 \mathrm{hr}$. (45.32\%). The less ability to ACE inhibition level was $13.45 \%$.

Effect of extraction time at $25^{\circ} \mathrm{C}$ on diabetic enzyme level of $F$. vulgare plant was demonstrated in Table 1 . Results revealed that $\alpha$-glucosidase inhibitor effectiveness of $F$.vulgare extract was $82.26 \%$ obtained at $8 \mathrm{hrs}$. However the less effective to inhibition level for $\alpha$-glucosidase was obtained at $0.5 \mathrm{hr}$. with value of $17.43 \%$. While methanol extract of $F$. vulgare exhibited $82.43 \%$ of $\alpha$-amylase inhibitor level. The lowest inhibitor level of $\alpha$-amylase was $47.04 \%$ at $1 \mathrm{hr}$.

\section{Effect of Extraction Time at $37^{\circ} \mathrm{C}$ on the Content Phenolic Compound, ACE and Diabetic enzymes in F. Vulgare}

The content of phenolic compounds extracted from F.vulgare plant increased gradually from $0.5 \mathrm{hr}$. to $8 \mathrm{hrs}$. The highest content of phenolic compounds was obtained at $8 \mathrm{hrs}$. with value of $17.04 \mathrm{mg} / \mathrm{g}$. While the lowest value was for $0.5 \mathrm{hr}$. with value of $12.44 \mathrm{mg} / \mathrm{g}$. The percentages of ACE inhibitor level were significantly compared with time. The lowest percentage to ACE inhibition was $13.34 \%$ at $2 \mathrm{hr}$. While highest percentage to ACE inhibition was $50.80 \%$ at 8 hrs. The highest inhibitor level for $\alpha$-amylase was $42.91 \%$ at $1 \mathrm{hr}$. whereas the highest inhibitor level was $59.91 \%$ at $4 \mathrm{hr}$ of $\alpha$-glucosidase. While the lowest inhibitor level of $\alpha$-amylase and $\alpha$-glucosidase were $27.03 \%$ and $21.75 \%$ at $0.5 \mathrm{hr}$. respectively. (Table 3 ).

\section{TABLE III: CONTENT OF PHENOLIC COMPOUNDS, ACE INHIBITORY} ACTIVITY (\%), A-GLUCOSIDASE INHIBITORY ACTIVITY (\%) AND A-AMYLASE INHIBITORY ACTIVITY (\%) FOR METHANOL EXTRACTION USING DIFFERENT TIME AT $37 \mathrm{C}^{\mathrm{O}}$

\begin{tabular}{|c|l|c|c|c|c|c|c|c|}
\hline \multirow{2}{*}{$\begin{array}{c}\text { Biological } \\
\text { properties }\end{array}$} & \multicolumn{7}{|c|}{$37 \mathrm{C}^{\mathrm{o}}$} \\
\cline { 2 - 8 } & $0.5 \mathrm{~h}$ & $1 \mathrm{~h}$ & $2 \mathrm{~h}$ & $4 \mathrm{~h}$ & $6 \mathrm{~h}$ & $8 \mathrm{~h}$ & & $\mathrm{SE}$ \\
\hline $\begin{array}{c}\text { Total } \\
\text { phenolic }\end{array}$ & $12.44^{\mathrm{b}}$ & $15.75^{\mathrm{a}}$ & $16.16^{\mathrm{a}}$ & $16.29^{\mathrm{a}}$ & $16.7^{\mathrm{a}}$ & $17.04^{\mathrm{a}}$ & 0.91 \\
\hline $\begin{array}{c}\text { ACE inhibitory } \\
\text { level }\end{array}$ & $25.4^{\mathrm{c}}$ & $20.57^{\mathrm{d}}$ & $13.34^{\mathrm{c}}$ & $30.22^{\mathrm{b}}$ & $21.7^{\mathrm{d}}$ & $50.8^{\mathrm{a}}$ & & 0.62 \\
\hline $\begin{array}{c}\alpha \text {-amylase } \\
\text { inhibitory level }\end{array}$ & $27.03^{\mathrm{c}}$ & $42.91^{\mathrm{a}}$ & $40.43^{\mathrm{ab}}$ & $40.98^{\mathrm{ab}}$ & $39.6^{\mathrm{b}}$ & $40.7^{\mathrm{ab}}$ & 0.95 \\
\hline $\begin{array}{c}\alpha \text {-glucosidase } \\
\text { inhibitory level }\end{array}$ & $21.75^{\mathrm{d}}$ & $31.29^{\mathrm{b}}$ & $32.48^{\mathrm{b}}$ & $59.91^{\mathrm{a}}$ & $28.16^{\mathrm{c}}$ & $26.22^{\mathrm{c}}$ & & 0.69 \\
\hline
\end{tabular}

*values with different letters in the same row are significantly different at $p<0.05$

** The values are means for two replicates and expressed as mg of Gallic acid equivalent (GAE)/g (of dry matter from the sample).

$* * * \mathrm{SE}=\mathrm{Standard}$ error

In present study, the effect phenolic extraction time and temperature on ACE inhibitory activity were varied significantly. The highest value of ACE inhibitory activity was obtained at $37^{\circ} \mathrm{C}$ for $8 \mathrm{hrs}$. with value of $50.80 \%$. Although, several studies reported that the extracted conditions of phenolic compounds from medicinal plants had a higher ACE inhibitor activity at higher temperature for short time due to increase the solubility and rate of diffusion of these compounds. However, using of higher temperature for long time of extraction process may have a degradation of phenolic compounds (Onofre et al., 2007). The ACE inhibitory activity of phenolic compounds in water extract at $100^{\circ} \mathrm{C} / 15 \mathrm{~min}$ from Alpinia galanga $\mathrm{L}$. rhizome and Alstonia scholaris L. bark were 51.37 and $52.89 \%$, respectively (Ying sukpisarn et al., 2005). The highest value of ACE inhibitory activity of phenolic compounds in Rhodiola species was extracted by ethanol at $40^{\circ} \mathrm{C}$ for $3 \mathrm{hrs}$. with value of $38.5 \%$ (Kwon et al., 2006). In this study, the optimal extraction temperature and time of inhibitory activity for diabetic enzymes were at $25^{\circ} \mathrm{C}$ for $8 \mathrm{hrs}$. with value of $82.0 \%$.

Bita et al. (2013) reported that the inhibitory activity of $\alpha$-amylase activity was $48 \%$ at $25^{\circ} \mathrm{C}$. These results are not in agreement with obtained results of Marshall and Lauda. (1975) who reported a 10 -fold increase in activity of the $\alpha$-amylase inhibitor when the temperature of the reaction was raised from $25^{\circ} \mathrm{C}$ to $37^{\circ} \mathrm{C}$. 


\section{CONCLUSION}

In this study, the methanol extract of phenolic compound from $F$. vulgare has highest inhibition of $\alpha$-amylase and $\alpha$-glucosidase at $25^{\circ} \mathrm{C}$ for $8 \mathrm{hrs} .82 .43 \%, 82.26 \%$, respectively, and moderate inhibition of ACE at $37^{\circ} \mathrm{C}$ for $8 \mathrm{hrs}$. (50.8\%). It may be concluded that the $\mathrm{F}$. vulgare extract have higher effect on level of diabetes and moderate effect on high blood pressure. Further study is required for extract and identification of bioactive compounds of $F$. vulgare plant and the effect on patients with diabetes and hypertension by applied to the experimental animals (in vivo).

\section{REFERENCES}

[1] Ali, H., Houghton, P and Soumyanath, A. (2006). $\alpha$-Amylase inhibitory activity of some Malaysian plants used to treat diabetes; with particular reference to Phyllanthus amarus. Journal of Ethnopharmacology, 107:449-455.

[2] Alu'datt. M., Ereifej, K. Abu-Zaiton, A. Alrababah, M. Almajwal, A. Rababah, T. and Yang, W. (2012). Anti-Oxidant, Anti-Diabetic, and Anti-HypertensiveEffects of Extracted Phenolic and Hydrolyzed Peptides from Barley Protein Fractions. International Journal of Food Properties, 15(4): 781-795.

[3] Appel, L.J. (2010). Intensive Blood-Pressure Control in Hypertensive Chronic Kidney Disease. New England Journal of Medicine, 363: 918-929.

[4] Bakris,G., Sowers, J. Epstein, M and Williams, M. (2000). Hypertension in patients with diabetes. Why is aggressive treatment essential Postgradualni Medicina, 107: 53-64.

[5] Basak, S.S and candan, F. (2010). Chemical composition and in vitro antioxidant and antidiabetic activities of Eucalyptus camaldulensis Dehnh. Essential oil. Journal of Iranian chemical Society, 7(1):216-226.

[6] Bernfeld, P. (1955). Amylases alpha and beta, In: Colowick, SP., Kaplan, NO (Eds) methods in Enzymology. Academic press, New York, 3(2):117-121.

[7] Bhandari, MR and Jong Annurakkun. (2008). Alpha amylase inhibitory activity of medicinal herbs pakhanbhed (Berginia ciliate). Food chemistry, 61:122-125.

[8] Bita, V., Zibaee, A and Jalali, J. (2013). Inhibition of digestive $\alpha$-amylase from chilo suppressalis walker (lepidotera: crambidae) by a proteinaceous extract of citrullus colocynthisl. (cucurbitaceae). Journal of plant protection research, 53(3): 19-25.

[9] Carson, E. (2000). Rationale for the use of combination angiotensin-converting enzyme inhibitor/angiotensin II receptor blocker therapy in heart failure. American Heart Journal, 140:361-366.

[10] Castro Braga, F., Wagner, H. Lombardi, A and de Oliveira, A. (2000). Screening the Brazilian flora for antihypertensive plant species for in vitro angiotensin-I-converting enzyme inhibiting activity. Phytomedicine, 7(3):245-50.

[11] Ceriello, A. (2005). Postprandial Hyperglycaemia and Diabetes Complications: Is It Time to Treat. Diabetes, 54.

[12] Choi, H. S., H. Cho, H.Yang, K. Ra, H. Suh, (2001). Angiotensin I-converting enzyme inhibitor from Grifola frondosa. Food Res. International, 34: 177-182.

[13] Conforti, F., Statti, G. Loizzo, R. Sacchetti, G. Poli, F and Menichini, F. ( 2005).In Vitro antioxidant effect and inhibition of alpha-amylase of two varieties of Amaranthus caudatus seeds. Biological and Pharmaceutical Bulletin, 28: 1098-1102.

[14] Cushman, D and Cheung, H. (1971). Spectrometric assay and properties of the angiotensin-converting-I-enzyme of rabbit lung. Biochemical Pharmacology, 20: 1637-1648.

[15] Gonz' alez-Montelongo, R., Lobo, M and Gonz' alez, M. (2010). Antioxidant activity in banana peel extracts: testing extraction conditions and related bioactive compounds. Food Chemistry, 119:1030-9.

[16] Grabitske, HA and Slavin, J. (2009). Gastrointestinal effects of low-digestible carbohydrates. Critical Reviews in Food Science and Nutrition, 49:327-360.
[17] Handa, SS., Khanuj, S. Longo, G and Rakesh, D. (2008). Extraction Technologies for Medicinal and Aromatic Plants. International centre for science and high technology. Trieste, 21-25.

[18] Kumar, S., Narwal, S and Kumar, V. (2011). $\alpha$-glucosidase inhibitors from plants: Natural approach to treat diabetes. Pharmacog, 9(5): 19-29.

[19] Kwon, I., Vattem, D and Shetty, K. (2006). Evaluation of clonal herbs of Lamiaceae species for management of diabetes and hypertension. Asia Pacific Journal of Clinical Nutrition, 15: 107-118.

[20] Lee, D., Kim, J. Park, J. hoi, Y and Lee, J. (2004). Isolation and characterization of a novel angiotensin I-converting enzyme inhibitory peptide derived from the edible mushroomTricholoma giganteum. Peptides, 25: 621-627.

[21] Maria John, KM., Rajesh, J. Mandal, A and Natarajan, S. (2011). European Journal of Experimental Biology, 135-145.

[22] Marshall, J.J and Lauda, C. (1975). Purification and properties of phaseolamin, an inhibitor of á-amylase, from the kidney bean Phaseolus vulgaris. Journal Biology Chemistry, 250 (20): 8030-8037.

[23] McCue, P.; Kwon, Y and Shetty, K. (2005). Anti-amylase, antiglucosidase and anti-angiotensin I-converting enzyme potential of selected foods. Journal of Food Biotechnology, 29: 278-294.

[24] McCue, P., Vattem, D and Shetty, K. (2004). Inhibitory effect of clonal oregano extracts against porcine pancreatic amylase in vitro. Asia Pacific Journal of Clinical Nutrition, 13:401-408.

[25] Muckensturm. B., Foechterlen, D. Reduron, J. Danton, $P$ and Hildenbrand, M. (1997). Phytochemical and chemotaxonomic studies of Foeniculum vulgare. Biochemical Systematics and Ecology, 25: 353-358.

[26] Nathan, DM., Buse, J and Davidson, M. (2006). Management of hyperglycaemia in type 2 diabetes: a consensus algorithm for the initiation and adjustment of therapy. A consensus statement from the American Diabetes Association and the European Association for the Study of Diabetes. Diabetologia. 49(8):1711-1721.

[27] Oktay, M., Gulcin, I and Kufrevioglu, I. (2003). Determination of in vitro antioxidant activity of fennel (Foeniculum vulgare) seed extracts. Food Science and Technology, 36: 263-71.

[28] Onofre, F.O., and Hettiarachchy, N. (2007). Extraction, quantification, and characterization of phenolics extracted with the aid of sonication from rice barn. Cereal Chemistry, 84(4): 337-342.

[29] Paul, M., Mehr, A and Kreutz, R. (2006). Physiology of local renin-angiotensin systems. Physiological Reviews, 86: 747-803.

[30] Preva-Uzunalic, A., Skerget, M. Knez, Z. Weinreich, B. Otto, F and Gruner, S. (2007). Extraction of active ingredients from green tea (Camellia sinensis): Extraction efficiency of major catechins and caffeine. Food Chemistry, 96: 597-605.

[31] Ramasubbu, N., Ragunath, C. Mishra, J. Thomas, M. Gyemant, G and Kandra, L. (2004). Human salivary alpha-amylase Trp58 situated at subsite-2 is critical for enzyme activity. European Journal Biochemistry, 271:2517-2529.

[32] Segura, J and Ruilope, L. (2006). Antihypertensive therapy in patients with metabolic syndrome. Current Opinion Nephrology Hypertension, 15: 493-497.

[33] Shlipak, M., Browner, W. Noguchi, H. Massie, B. Frances, C and McClellan, M. (2001) Comparison of the effects of angiotensin converting-enzyme inhibitors and beta blockers on survival in elderly patients with reduced left ventricular function after myocardial infarction. American Journal of Medicine, 110:425-433. 